\title{
A Study on the Entrepreneurial Intention among Student
}

\author{
Dr. Nanu Lunavath ${ }^{1}$ \\ Associate Professor, School of Management, Aarushi Group of Institution, Warangal -4,Telangana
}

\begin{abstract}
This paper focuses on entrepreneurship intensions among student, the entrepreneurial self-confidence of the student and the perception/opinion on entrepreneurial intention in India continue to face limitation in terms of societal pressures and self-confidence constraints. Entrepreneurship education may mitigate these limitations for those respondents with entrepreneurial aspiration. In this way entrepreneurship education can be positioned as an equalizer, possibly reducing the limiting effects of low self-confidence and ultimately increasing the chances for successful venture creation by motivating the student to take an entrepreneurship. This paper aims to measure and identify determinants of entrepreneurial intention among the professional course student pursuing Engineering and Management in various institution in Andhra Pradesh. The survey among the students by taking a sample size of 300 students from the various institutions. The Personal factors include self-efficacy, family background, influence of role models and institution environment of research base projects and its conversion, entrepreneurial education, faculty influence etc.
\end{abstract}

Keywords: Entrepreneurial intention, personal factors, situational, education institution.

\section{ENTREPRENEURIAL INTENTION}

Entrepreneurship is defined as the process of organizational emergence (Gartner, 1992). Entrepreneurial intentions are crucial to this process, forming the first in a series of actions to organizational founding (Bird, 1988). Moreover, intentions toward a behavior can be strong indicators of that behavior ( Fishbein and Ajzen, 1975). Our understanding of entrepreneurial intentions is guided by two models: Ajzen's (1991) theory of planned behavior (TPB), and Shapero and Sokol's (1982) model of the entrepreneurial event (SEE). TPB was developed to explain how individual attitudes towards an act, the subjective norm, and perceived behavioral control are antecedents of intentions. Entrepreneurial intent has proven to be a primary predictor of future entrepreneurial behavior (Katz, 1988; Reynolds, 1995; Krueger, 2000). Therefore, investigating what factors determine the entrepreneurial intent is a crucial issue in entrepreneurship research. In general, intent can be defined as "a state of mind directing a person's attention toward a specific object or a path in order to achieve something" (Vesalainen and Pihkala, 1999,). A central question that arises is what factors determine entrepreneurial intent among student.

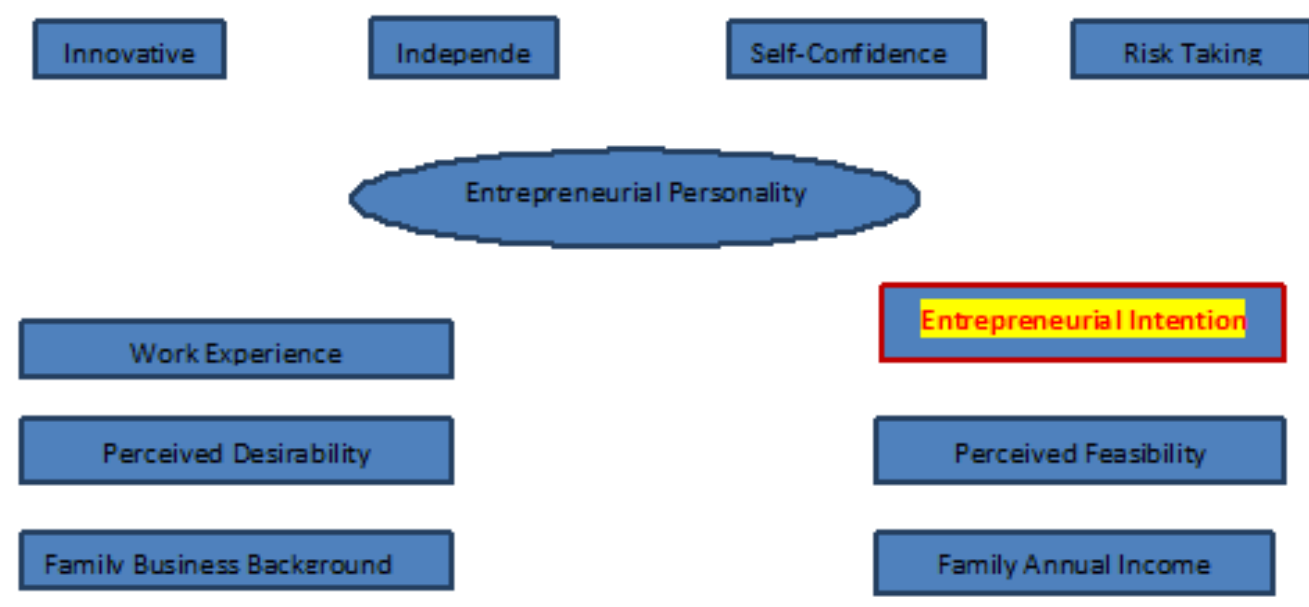

The objective of the paper is to examine key factors influencing professional student' entrepreneurial intention. Based on previous research, we incorporate both internal and external influence factors. In particular, we investigate the effect of individuals' attitudes on their choice of entrepreneurial carrier. In this paper the sample size includes student of professional course like Engineering (graduates and post graduates) and Management from different

\footnotetext{
${ }^{1}$ Corresponding Author: nanulunavath@gmail.com
} 


\section{American Research Journal of Business and Management, Volume 1 Issue 1, February 2015 ISSN 2379-1047}

technical Institutions in Andhra Pradesh. The total sample size being 300 includes 210 male and 90 female students. Random sampling method was used for sample selection. The survey was conducted by administering an instrument including the demographic details in the part A. Which was followed with a set of statements in Part B measures the entrepreneurial intention among the student.

\section{OBJECTIVE OF THE STUDY}

To study the entrepreneurship intensions among student

To identify the entrepreneurial self-confidence of the student

To understand the perception/opinion of entrepreneurship among the student

\section{Methodology}

This study aims to analyses the entrepreneurial intentions of student. The researcher assumed that certain entrepreneurial intentions and their background motivate persons to become entrepreneurs. In order to access the curriculum of education, it was considered appropriate to administer a structured questionnaire to the student. A structured questionnaire was designed to gather the data required for this research. The research instrument was $\mathrm{s}$ structured into two parts. The first part included Personal background of the respondents and the second part included variable to measures entrepreneurial intention, education and perception/opinion on entrepreneurships. A total of 300 students were chosen for the study in the Warangal district of Andhra Pradesh was drawn up and using a random sampling technique were used. The study was based on both primary and secondary sources. The primary data was collected from 300 students. The data collected was content analyzed and presented in the form of a table and graphs. The secondary data was collected from books, journals, websites and other literature available.

\section{LIMITATIONS}

Sample size was limited to 300 because of limited time which is small to represent the whole population. The sample size may not adequately represent to the situation.

Simple random sampling techniques is due to time and financial constraints

\section{DATA ANALYSIS AND INTERPRETATION}

\subsection{Education}

Education is an important determinant of Social class. It is an important instrument of increasing and betterment of the change of student employability and empowering themselves. Education has been reposted as a crucial factor for developing modern entrepreneurship and it accelerates the entrepreneurial spirit the table shows the education qualifications of respondents. In this ever-changing and most competitive world of business entrepreneurs must have good technical and professional background. This is also one of the reasons for the failure of many entrepreneurs.

\begin{tabular}{|c|c|c|}
\hline $\begin{array}{c}\text { Computer } \\
\text { Application (MCA } \\
\text { etc.,) } \\
45 \\
15 \% \\
\text { Business } \\
\text { Management (All } \\
\text { Branches), } 147,49 \%\end{array}$ & $\begin{array}{l}\text { Engineering ( All } \\
\text { Branches) } \\
108 \\
36 \%\end{array}$ & $\begin{array}{l}\text { Engineering ( All } \\
\text { Branches) } \\
\text { Business Management (All } \\
\text { Branches) } \\
\text { Computer Application } \\
\text { (MCA etc.,) }\end{array}$ \\
\hline
\end{tabular}

Source: Compiled from questionnaire data

It is reveals that about 49 percent of students are studying management and allied areas courses followed by Engineering with 36 per cent (all branches) and Master of Computer Application with 15 per cent. The analysis indicates that the majority of the respondent are pursuing are education with a focus of Management. 


\subsection{Distribution of Age of Students}

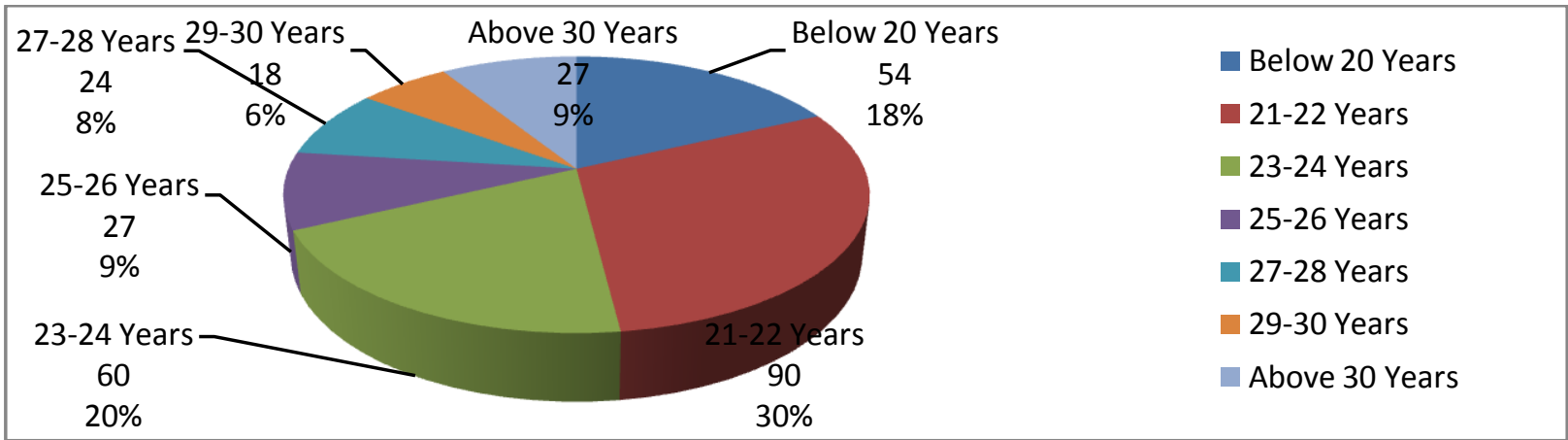

Source: Compiled from questionnaire data

The result shows that 30 per cent of the respondents belonging age group 21-22 years followed by 23-24 years with 20 per cent. The reveal that most of the respondents age group 20-25 years.

\subsection{Family Backgrounds}

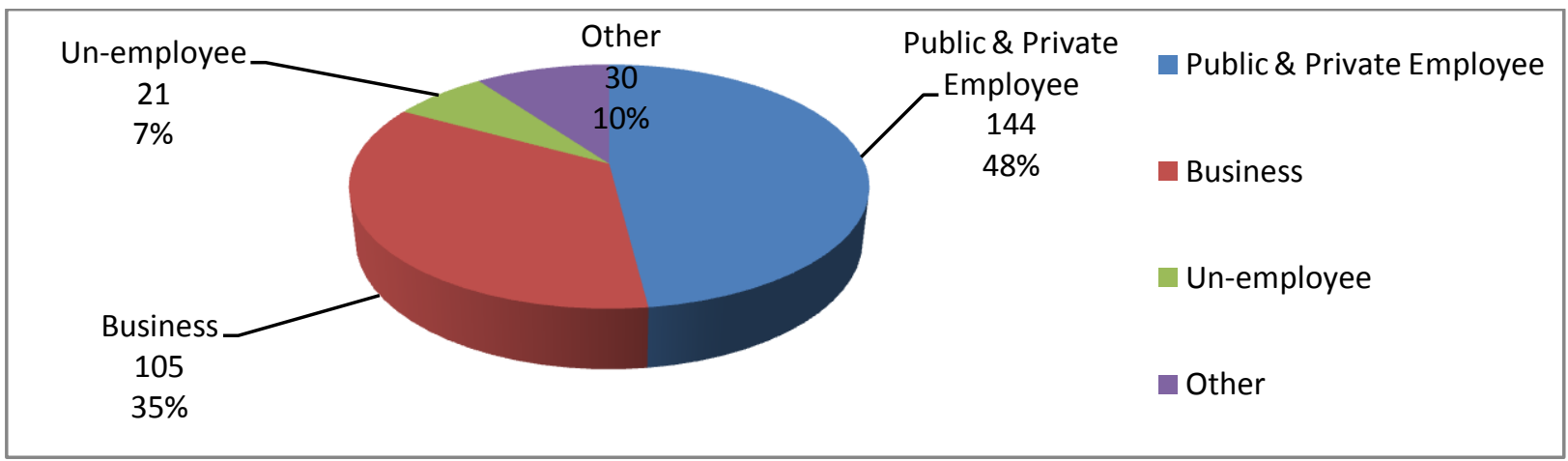

Source: Compiled from questionnaire data

The vast majority of the respondent's family backgrounds are employed in private \& Public sector with 48 percentage remaining business with 35 percentages and un-employee with only 7 percentages. Clearly the results indicate that the respondents were more inclined to pursue public and private sector career and that entrepreneurial intention appear to be limited.

\section{Problem Being an ENTrepreneurship}

It is true that the entrepreneurs have come from diverse economic social and geographical background inter alias, influence is entrepreneurial spirit. However, as it is rightly pointed out, that immediately conceding is not their miles rather the factors which have ultimately influenced them to take to the entrepreneurial motivation and entrepreneurial ability to make correct decisions by knowing reasons for his entry into the present business. To bring out the immediate factors which influenced the women entrepreneur to accept entrepreneurships as a career the respondent were to give the reasons and choosing the present line of business

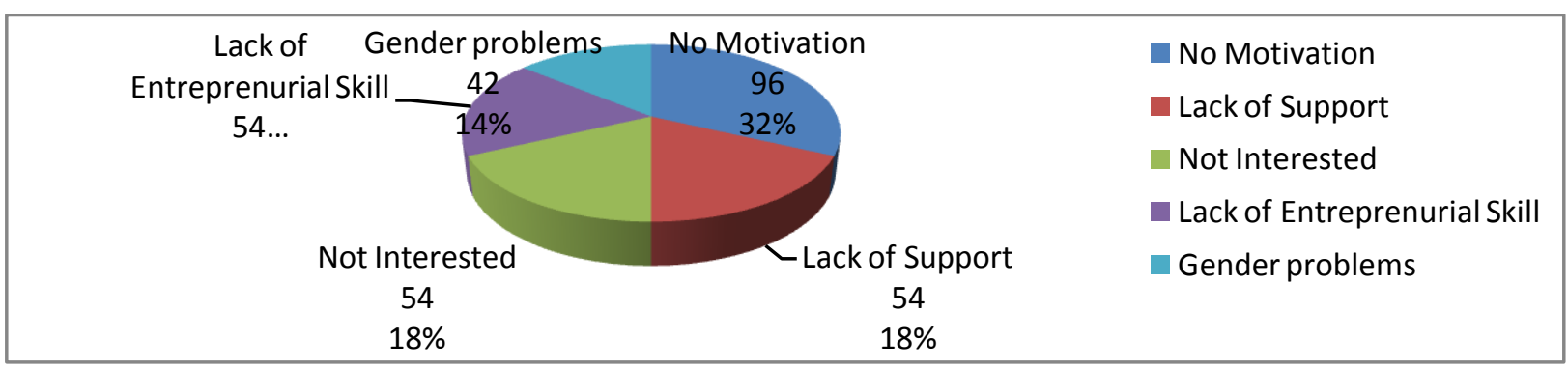

Source: Compiled from questionnaire data. 
Factors which were identified as important were and included in the questionnaire. But a majority of its respondents gave more reasons for entry into entrepreneurship as several reasons that gives ranks of different reasons for finding out major reasons which brought them into entrepreneurship.

The result suggest that the majority of the respondents felt that there was no motivation to pursue career an entrepreneur as opposed to being not interested greater concern is the number of respondents who choose not to pursue an entrepreneurship career because of the lack of support or because they felt their gender was a limiting factors.

\section{SOURCE OF INITIAL IDEA}

In addition to the various factors which influenced the entrepreneurs to choose entrepreneurship as a career the data pertaining to importance source of initial idea was also collected to shed light on the various source which were responsible for starting their enterprise Table given below explain different sources from which women entrepreneurs got initial idea.

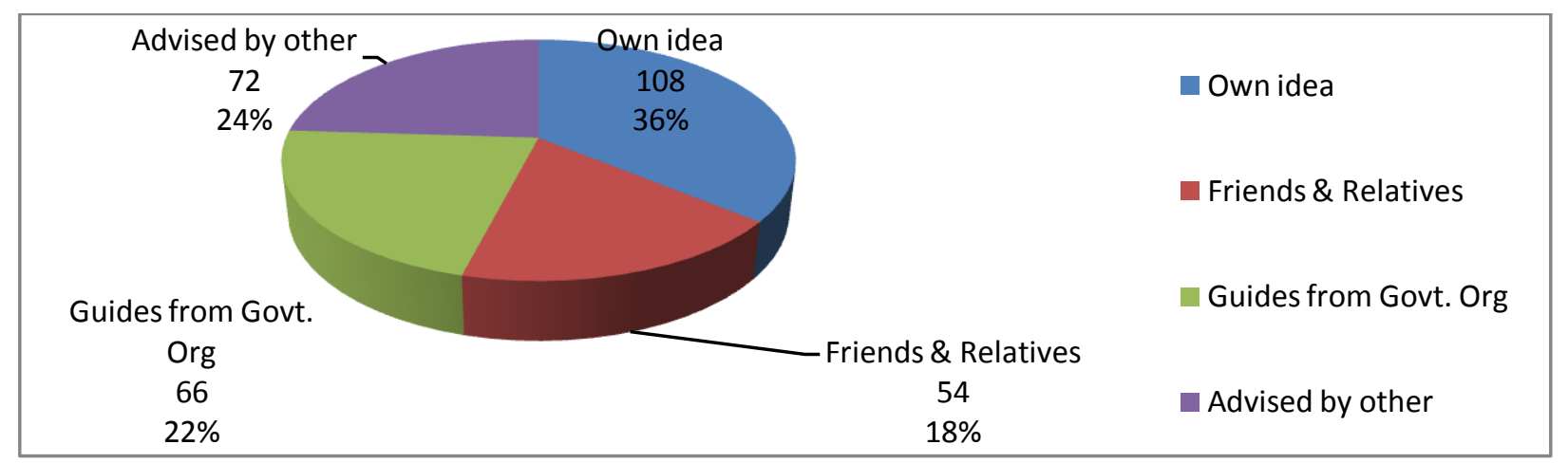

Source: Compiled from questionnaire data.

It is gratifying to note that as many as (36\%) of respondent got the initial idea of starting the enterprise on their own followed by A good number of Women entrepreneurs also got idea of starting enterprise advised by friends and relatives.

\section{HOW TO DEVELOP STUDENT ENTREPRENEURS}

First of all, it is necessary to create an enterprising environment in the economy as well as entrepreneurial attitudes among the unemployed youth. For this the youngster should be connected intimately with the business. So for, the efforts by the academic institutes towards promoting entrepreneurship are largely unsatisfactory. Most of the Technical and professional institution in the countries ignore this aspect and put emphasis mainly on training and placement of their student. Considering the need of the day, these institutes, along with their training \& placement cell should form a separate cell to encourage and guide their student towards entrepreneurship development in the line of their technical and or professional knowledge and enterprise. This quite important as in also present era of technology and market driven discontinuity and knowledge dominance, educated persons have definite advantage over other in spotting the appropriate venture and running the same successfully. Right efforts on from are areas required in the development of student entrepreneurs and their great participation in the entrepreneurial activities.

\section{CONClusion \& Suggestion}

Following efforts can be taken into account for effective development of student entrepreneurs.

1. Association of student entrepreneurs should assume responsibility of creating a greater awareness among student similarly efforts shall be made by all association throughout the country. This program can be linked up with youth programs of educations. Programs on a continuous basis have to be designed planned and implemented for the benefit of student in all university of our country to attractive young student to take up entrepreneurial activates

2. The university should setup consultancy center for student entrepreneurs

3. Activities of different programs on development should be highly coordinated to avoid wastage of funds. 


\section{American Research Journal of Business and Management, Volume 1 Issue 1, February 2015}

ISSN 2379-1047

4. Political interference in such program should be kept at minimum. Government should also encourage private investigated in sub programs.

5. Adequate insurance coverage should provide to the industrial and business units promoted by student entrepreneur agriculturist the business risks (financial losses) in order to safeguard and interest of the entrepreneur as well as the employees of the enterprise.

6. Marketing assistance schemes and necessary for economically to provide quality product at reasonable and high rates to their finished products and introduce common brand names.

7. Entrepreneurial development program conduct training to respective product.

8. Consider student as specific target group for all development programs.

9. Training and counseling on a large scale of existing student entrepreneurs to remove psychological causes like lack of self-confidence and fear of success.

10 Counseling through the aid of committed NGO's, psycho logistics, managerial experts and technical personnel should be provided to existing and emerging student entrepreneurs.

11 A student's entrepreneur's guidance cell set up to handle the various problems of student entrepreneurs.

12 Industrial estates could also provide marketing outlets for the display and sale of products made by student. District Industries centers and single window agencies should make use of assisting student in their trade and business guidance.

Training in entrepreneurial attitude should start at the high school level through well designed courses, which could build Confidence through behavioral games. Entrepreneurship among student, no doubt improves the wealth of the nation in general and of the family in particular. Student today are more willing to take up activities. Student entrepreneurship must be molded properly with entrepreneurial traits and skills to meet the change in trends, challenges global markets and also be competent enough to sustain and strive for excellence in the entrepreneurial arena.

\section{REFERENCES}

[1] Bandura, A., 1986. Social Foundations of Thought and Action: A Social Cognitive Theory . Prentice-Hall, Englewood Cliffs, NJ.

[2] Baty Entrepreneurship to win-Prentice Hall Inc. 1979

[3] Bechard, J. \& Gregoire, D. (2005). Entrepreneurship education research revisited: The case of higher education. Academy of Management Learning and Education, 4(1), 22- 43

[4] Bird .B. (1988), Implementing entrepreneurial Ideas: The case for Intentions . Academy of Management Review, Vol. 13, No.3, $442-453$.

[5] Crant, J.M., 1996. The proactive personality scale as a predictor of entrepreneurial intentions. Journal of Small Business Management 34, 42-49.

[6] Chen, C.C., Greene, P.G., Crick, A.,1998. Does entrepreneurial self-efficacy distinguish entrepreneurs from managers? Journal of Business Venturing 13 (4), 295-316.

[7] Dhameja S K(2002), Student Entrepreneurs Opportunities, performance, problems. Deep publictions (P) Ltd New Delhi

[8] Davidsson, P, Wiklund, J, 2001. Levels of analysis in entrepreneurship re-search: current research practice and suggestions for the future. Entrepreneurship Theory and Practice 25 (4), 81- 100.

[9] Degeorge J.M. \&Fayolle .A. (2008). Is entrepreneurial intention stable through time? First insights from a sample of French student. International Journal on Entrepreneurship and small business management, Vol.5, No.1, 1-25.

[10] Fishbein, M. (1990) The role of desires, self-predictions, and perceived control in the prediction of training session attendance, Journal of Applied Social Psychology, 20, pp. 173-198.

[11] Gopalan, S. Employment of Student. The Indian Situation: 2nd InternationalConference of Student Entrepreneurs, NAYE, New Delhi, 1981.

[12] Gartner,W.B., Bird, B.J., Starr, J.A., 1992. Acting as if: differentiating entrepreneurial from organizational behavior. Entrepreneurship Theory and Practice.

[13] Hadimani, R.N. Dynamics of Industrial Entrepreneurship -Ashish Publishing House NewDelhi 1985.

[14] Krueger, N.F., Carsud, A.L., 1993. Entrepreneurial intentions: applying the theory of planned behavior. Entrepreneurship \& Regional Development 5 (4), 315-330. 


\section{American Research Journal of Business and Management, Volume 1 Issue 1, February 2015}

ISSN 2379-1047

[15] Kolvereid, L., 1996. Prediction of employment status choice intentions. Entrepreneurship Theory and Practice 21 (1), 4757.

[16] Linan, F., Chen, Y.W., 2009. Development and cross-cultural application of a specific instrument to measure entrepreneurial intentions. Entrepreneurship Theory \& Practice 593-617 (May).

[17] Kourilsky, M. \& Walstad, M. (1998). Entrepreneurship and female youth: Knowledge, attitudes, gender differences and educational practices. Journal of Business Venturing, 13, 77- 88.

[18] Markham, G.\& Baron, R. (2002). Inventors and new venture formation: The effects of general selfefficacy and regretful thinking. Entrepreneurship Theory and Practice, 27(2) 149- 165.

[19] National Seminar on Entrepreneurship Development in Small Scaleindustries, Summary of Proceeding Controller of Publication, New Delhi, 1975.

[20] Segal, G., Borgia, D., \& Schoenfeld, J. 2002). Using social cognitive career theory to predict self- employment goals. New England Journal of Entrepreneurship, 5(2), 47- 56.

[21] Shapero, A. \& Sokol, L. (1982). The social dimensions of entrepreneurship. In $\quad$ C. Kent, D. Sexton, \& K. Vesper (Eds.), The encyclopedia of entrepreneurship. New York: Prentice Hall.

[22] Sharma Sheetal (2006) "Educated student, powered, student" Yojana Vol. 50

[23] Singh,P.NDevelopment Entrepreneurship for Economic Growth Vikas publishing 1980

[24] Shiva Ramu, S. Entrepreneuship and Enterprise Growth-Seema publication 1985.

[25] Vasanth Desai Dynamics of Entrepreneurs Development and Management -Himalaya Publishing House New Delhi 1997. 